\title{
Elevation of sputum matrix metalloproteinase-9 persists up to 6 months after smoking cessation: a research study
}

\author{
Noora Louhelainen ${ }^{1}$, Harri Stark², Witold Mazur ${ }^{1}$, Paula Rytilä ${ }^{3}$, Ratko Djukanovic ${ }^{4}$, Vuokko L Kinnula ${ }^{1 *}$
}

\begin{abstract}
Background: Smoking cessation is the best possible way to prevent the progression of smoking related airway diseases. However, the effect and time scale of smoking cessation on airway inflammation/remodelling are largely unknown. This prospective study evaluated the effects of smoking cessation on induced sputum (IS) neutrophils, matrix metalloproteinases (MMP-7, -8, -9) and tissue inhibitor of metalloproteinase-1 (TIMP-1).

Methods: A total of 61 subjects participated in the study; 17 stopped smoking for 3 months and 9 for 6 months. The proportion of IS neutrophils and the levels of MMPs and TIMP-1 by ELISA were determined at baseline and at 3 and 6 months after cessation.

Results: In the smokers, baseline IS neutrophils, MMPs and TIMP-1 were significantly higher compared to nonsmokers. Levels of MMP-7, -8 and TIMP-1 decreased nearly to those of non-smokers but the levels of MMP-9 increased significantly from the baseline of the same subjects at 3 months after cessation $(p=0.009)$ with no significant decline at 6 months after cessation.
\end{abstract}

Conclusions: Sputum MMP-9 remained elevated after 6 months of smoking cessation, which may contribute to ongoing lung damage typical of COPD.

\section{Background}

Chronic obstructive pulmonary disease (COPD) is one of the most important causes of death all over the world [1]. Smoking is the single most important risk factor of COPD and smoking cessation the only intervention that is able to reduce the disease progression [2,3]. Smoking asthmatics have been excluded from most investigations, but it is known that the inflammatory profile in these subjects is very similar to COPD, with one of the most important features being the influx of neutrophils to the airways in asthma [4]. There is a remarkable overlap in many features in smokers with asthma and subjects with COPD; recent studies even suggest that the majority of older people may suffer from both asthma and COPD [5]. It is not known how the smoking cessation exactly changes the airway inflammatory processes in chronic smokers with or without asthma or COPD.

\footnotetext{
* Correspondence: vuokko.kinnula@helsinki.fi
'Department of Medicine, Division of Pulmonary Medicine, University of

* Correspondence: vuokko.kinnula@helsinki.fi
'Department of Medicine, Division of Pulmonary Medicine, University of Helsinki, Helsinki, Finland
}

(c) 2010 Louhelainen et al; licensee BioMed Central Ltd. This is an Open Access article distributed under the terms of the Creative Commons Attribution License (http://creativecommons.org/licenses/by/2.0), which permits unrestricted use, distribution, and reproduction in any medium, provided the original work is properly cited. airway inflammation and oxidative stress persists after smoking cessation over months in subjects with chronic bronchitis and COPD [6-8]. Evidence of ongoing inflammation has been documented via the increased levels of neutrophils and eosinophils in bronchoalveolar lavage (BAL) fluid, CD4+ and CD8+ cells in bronchial biopsy specimens and eosinophilic cationic protein (ECP) in sputum. The majority of the studies assessing the effects of smoking cessation on airway inflammation have been cross-sectional and there is a lack of prospective investigations.

Extracellular matrix (ECM) deposition is one pathological form of the tissue remodelling detected in the airways $[2,9,10]$. Matrix metalloproteinases (MMPs) have an important role in the breakdown of ECM and they are considered as biomarkers of tissue damage in several smoking related lung diseases [10-12]. Over 30 MMPs have been characterized, many of which are activated by smoking and/or oxidative stress $[13,14]$. The levels of MMP- 8 and -9 have been shown to be elevated in both 
experimental emphysema and COPD [10,15,16]. Levels of MMPs on sputum, mainly MMP-9, are also elevated in asthma when compared to the controls [17]. TIMP-1 (tissue inhibitor of metalloproteinases-1) is the major endogenous inhibitor of MMP-8 and -9 , and the levels of this protein are elevated in COPD [15]. MMP-7 is produced by alveolar macrophages, breaks down elastin and has an important role in the maintenance of innate immunity proteolytically activating anti-bacterial peptides in the lung [12]. Its role in asthma and COPD remains to be clarified $[10,17]$.

Induced sputum (IS) collection is a non-invasive method for assessment of airway inflammation in the airways. In the future, useful biomarkers may also be identified in IS, to permit accurate determination of the many phenotypes of smoking-related diseases $[18,19]$.

This prospective study was undertaken to assess if smoking cessation is associated with changes in numbers of neutrophils, and the levels of MMP-7, $-8,-9$ and TIMP-1 in induced sputum specimens. Inflammatory markers were determined at baseline and at three and six months after quitting of smoking to better understand the time course of smoking related alterations and possible temporal differences in the levels of the MMPs. The results were also compared to the corresponding values obtained from non-smoking controls. This is the first prospective study where the effects of smoking cessation on human MMPs have been assessed.

\section{Methods}

\section{Subjects}

Originally, 61 volunteer individuals consisting of 25 asymptomatic smokers, 15 smokers with mild asthma defined according to GINA [20], 7 with chronic bronchitis (previous Stage 0 COPD by GOLD criteria i.e. symptomatic smokers) and 14 subjects with GOLD Stage 1-2 COPD $[1,21]$ were recruited to the study.
There were 11 asthmatics and two subjects with COPD using inhaled steroids (daily doses ranging from 400 to $2000 \mu \mathrm{g})$. All the asthmatics and five subjects with COPD had short-acting $\beta_{2}$-agonists as rescue medicine. The subjects were advised to terminate smoking by a research nurse and were provided available pharmaceutical therapies i.e. nicotine products and bupropion to support their abstinence, based on the instructions by the physicians. Smoking cessation was confirmed by exhaled carbon monoxide analysis. The group of nonsmokers included never smokers or ex-smokers who had stopped smoking at least 20 years previously. Three of the smokers, three of the COPD patients and 6 asthmatics revealed at least one positive reaction in the skin prick test analyses for common aeroallergens (birch, grass, mugwort, Cladosporium herbarum, cat, dog, horse, and the house dust mite Dermatophagoides pteronyssinus). The subject characteristics of the smokers and non-smokers, who were also included in the study, are given in Table 1.

The study protocol was accepted by the Ethics Committees of the Helsinki University Hospital and the Southampton University Hospital, and it was performed according to principles of Helsinki Declaration [22]. The subjects provided a written permission for participating in the study.

\section{Lung function tests}

Standard spirometric values (Medikro M 904, Kuopio, Finland) were performed according to ATS/ERS recommendations [23]. Reference values compiled by Viljanen et al. [24] for Finnish population were used.

\section{Sputum induction}

As recommended by the ERS Task Force, the subjects inhaled hypertonic saline in order to provoke IS production [18]. Four volumes of dithioerythritol (DTE, Sigma,

Table 1 Subject characteristics of all the patients recruited for the smoking cessation.

\begin{tabular}{lllll}
\hline & Non-smoking controls & Asymptomatic Smokers & Smokers with smokers & Chronic asthma bronchitis/COPD \\
\hline Subjects $(\mathrm{n})$ & 30 & 25 & 15 & 21 \\
Female/male & $7 / 23$ & $15 / 10$ & $9 / 6$ & $14 / 7$ \\
Age yrs & $56 \pm 8$ & $42 \pm 12$ & $42 \pm 12$ & $56 \pm 10$ \\
Pack-yrs & $4 \pm 8$ & $23 \pm 15$ & $22 \pm 14$ & $39 \pm 15$ \\
& & & & $3.0 \pm 0.66$ \\
Post-bronchodilator & $3.9 \pm 0.60$ & $4.2 \pm 0.70$ & $102 \pm 38$ \\
FVC L* & $102 \pm 9$ & $99 \pm 14$ & $103 \pm 17$ & $2.1 \pm 0.72$ \\
FVC \% pred & $4.0 \pm 0.65$ & $3.2 \pm 0.49$ & $3.5 \pm 0.55$ & $79 \pm 8$ \\
FEV1 L* & $104 \pm 12$ & $97 \pm 8$ & $99 \pm 14$ & $69 \pm 15$ \\
FEV1\% pred* & $83 \pm 1$ & $80 \pm 9$ & 15 \\
FEV1/FVC & $82 \pm 4.4$ &
\end{tabular}

Data presented as mean \pm SD or median (range). FVC: forced vital capacity; \% pred: \% predicted; FEV1: forced expiratory volume in one second; *: $p<0.01 ;{ }^{* *}: \mathrm{p}$ $<0.001$. \#: baseline levels at once after smoking cessation. 
Germany) were added as the weight of the sample. The supernatant was frozen at $-80^{\circ} \mathrm{C}$ for biochemical analyses. Cell viability was studied by Trypan blue in a Burker chamber.

Cytocentrifuge preparations were made by Cytospin (Shandon Cytospin 3) and centrifuged at $450 \mathrm{rpm}$ for 6 minutes. The slides were stained by May-GrunwaldGiemsa-staining (Merck, Germany) for cell differential counts with 400 cells being counted from each slide. If the samples had less than $70 \%$ of squamous epithelial cells they were accepted for further assessments. The slides were frozen at $-20^{\circ} \mathrm{C}$.

The IS levels of MMP-7, -8, -9 and TIMP-1 were studied at the onset of smoking cessation and three and six months later. The numbers of neutrophils were assessed at the same time points.

MMP-7, MMP-8, MMP-9 and TIMP-1 analyses

MMP-7, MMP-8, MMP-9 and TIMP-1 concentrations were analysed by commercial ELISA kits (Amersham Biosciences, Cardiff, UK) according to the manufacturer's instructions. The detection limits were $0.016 \mathrm{ng} /$ $\mathrm{ml}$ for MMP-7, $0.032 \mathrm{ng} / \mathrm{ml}$ for MMP-8, $0.6 \mathrm{ng} / \mathrm{ml}$ for MMP-9 and $3.13 \mathrm{ng} / \mathrm{ml}$ for TIMP-1.

\section{Statistical methods}

The data are given as means (standard deviation) or medians (range). Values between groups were analysed with Mann-Whitney U and Kruskal-Wallis tests. The differences in MMP levels between two time points (baseline vs. three months after smoking cessation, baseline vs. six months after cessation, three months vs. six months after cessation) were analysed by Wilcoxon signed rank test. The data were analysed by SPSS for Windows 15.0 (SPSS Inc., Chicago, IL, USA) and a pvalue $<0.05$ was considered statistically significant.

\section{Results}

There were 17 subjects who successfully stopped smoking for a time of three months and 9 for half a year. Characteristics of these subjects are given in Table 2. Of these 17 individuals, six were asymptomatic smokers, four had mild asthma and seven were suffering from chronic bronchitis or COPD (one with previous GOLD

Table 2 Subject characteristics of the patients who quitted smoking.

\begin{tabular}{|c|c|c|c|}
\hline & Asymptomatic smokers & Smokers with asthma & Chronic bronchitis/COPD \\
\hline \multicolumn{4}{|l|}{ Subjects (n) } \\
\hline $3 \mathrm{mo}$ & 6 & 4 & 7 \\
\hline $6 \mathrm{mo}$ & 4 & 4 & 1 \\
\hline \multicolumn{4}{|l|}{ Female/Male } \\
\hline $3 \mathrm{mo}$ & $3 / 3$ & $3 / 1$ & $4 / 3$ \\
\hline $6 \mathrm{mo}$ & $3 / 1$ & $3 / 1$ & $1 / 0$ \\
\hline \multicolumn{4}{|l|}{ Age yrs } \\
\hline $3 \mathrm{mo}$ & $47 \pm 6$ & $46 \pm 2$ & $59 \pm 11$ \\
\hline $6 \mathrm{mo}$ & $50 \pm 5$ & $46 \pm 2$ & 57 \\
\hline \multicolumn{4}{|l|}{ Pack-yrs } \\
\hline $3 \mathrm{mo}$ & $15 \pm 10$ & $21 \pm 18$ & $36 \pm 14$ \\
\hline $6 \mathrm{mo}$ & $19 \pm 11$ & $21 \pm 18$ & 21 \\
\hline \multicolumn{4}{|l|}{ Post-bronchodilator } \\
\hline \multicolumn{4}{|l|}{ FVC L } \\
\hline $3 \mathrm{mo}$ & $4.2 \pm 0.65$ & $3.7 \pm 0.68$ & $2.9 \pm 0.48$ \\
\hline $6 \mathrm{mo}$ & $3.9 \pm 0.67$ & $3.7 \pm 0.68$ & 3.5 \\
\hline \multicolumn{4}{|l|}{ FVC \% pred } \\
\hline $3 \mathrm{mo}$ & $95 \pm 6$ & $99 \pm 27$ & $85 \pm 9$ \\
\hline $6 \mathrm{mo}$ & $96 \pm 6$ & $99 \pm 27$ & 83 \\
\hline \multicolumn{4}{|l|}{ FEV1 L } \\
\hline $3 \mathrm{mo}$ & $3.5 \pm 0.68$ & $3.0 \pm 0.53$ & $2.1 \pm 0.43$ \\
\hline $6 \mathrm{mo}$ & $3.2 \pm 0.71$ & $3.0 \pm 0.53$ & 2.35 \\
\hline \multicolumn{4}{|l|}{ FEV1\% pred } \\
\hline $3 \mathrm{mo}$ & $96 \pm 5$ & $98 \pm 26$ & $75 \pm 8$ \\
\hline $6 \mathrm{mo}$ & $97 \pm 6$ & $98 \pm 26$ & 70 \\
\hline \multicolumn{4}{|l|}{ FEV1/FVC } \\
\hline $3 \mathrm{mo}$ & $83 \pm 4$ & $82 \pm 2$ & $71 \pm 7$ \\
\hline $6 \mathrm{mo}$ & $82 \pm 5$ & $82 \pm 2$ & $82 \pm 2$ \\
\hline
\end{tabular}




\section{Neutrophils}

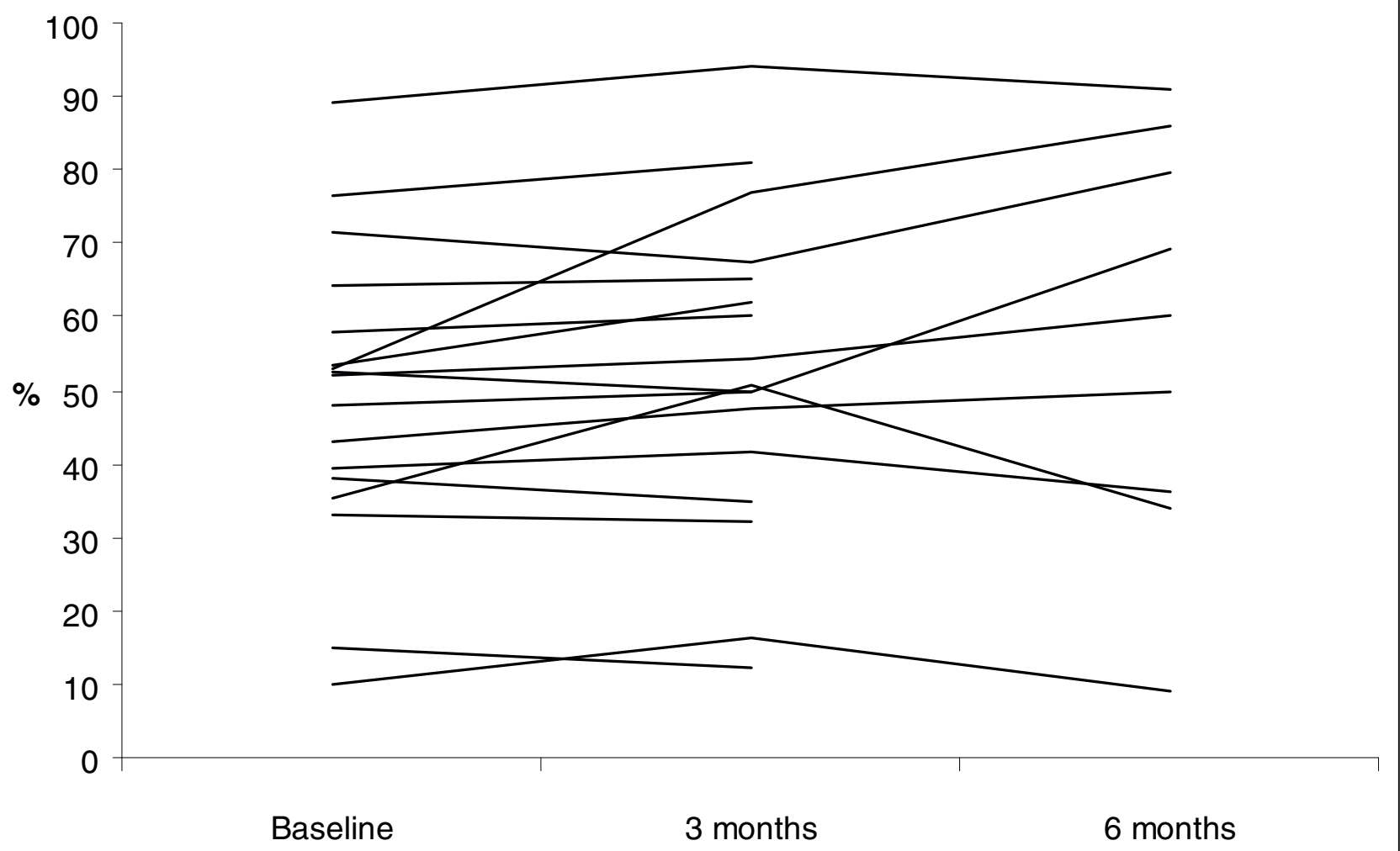

Figure 1 The percentage of induced sputum (IS) neutrophils in the smoking cessation group ( $n=17$, see Table 2 ) at the onset of smoking cessation (baseline) and at $\mathbf{3}$ and $\mathbf{6}$ months after stopping smoking. IS neutrophils were significantly higher in the smoking cessation group at the baseline compared to the non-smokers $(p=0.021)$. Neutrophils increased significantly from baseline at 3 months after cessation $(p=0.035)$ and declined to the levels of non-smokers at 6 months after the cessation.

Stage 0 and six with Stage 1 i.e. mild COPD). Four asymptomatic smokers, four asthmatic individuals and one subject with COPD succeeded in quitting smoking for six months. All subjects who completed the study had measurements at baseline and at 3 and 6 months. Due to the high number of dropouts, the three subgroups became small. The subjects in these subgroups were either asymptomatic or symptomatic smokers, or had mild asthma or mild COPD. Therefore, in the MMP analyses these three groups were assessed as a single group. The inflammatory profile in the sputum of these smokers revealed neutrophil predominance. In smokers and in non-smokers the percentages of neutrophils and the total count for neutrophils were $54.5 \pm$ $18.7 \%$ vs $30.0 \pm 12.0 \%$ and $2.2 \pm 3.1\left(10^{\wedge} 6 \mathrm{cells} / \mathrm{ml}\right)$ vs $0.42 \pm 0.55\left(\times 10^{\wedge} 6\right.$ cells $\left./ \mathrm{ml}\right)$, respectively. The levels of the MMP-7, $-8,-9$ and TIMP-1 in smokers and nonsmokers were $12.7 \pm 11.5 \mathrm{ng} / \mathrm{ml}$ vs $1.7 \pm 0.96 \mathrm{ng} / \mathrm{ml}$, $91.7 \pm 113.5 \mathrm{ng} / \mathrm{ml}$ vs $22.0 \pm 29.3 \mathrm{ng} / \mathrm{ml}, 50.1 \pm 63.2$ $\mathrm{ng} / \mathrm{ml}$ vs $21.9 \pm 11.9 \mathrm{ng} / \mathrm{ml}$ and $1383.3 \pm 1322.2 \mathrm{ng} / \mathrm{ml}$ vs $822.3 \pm 582.7 \mathrm{ng} / \mathrm{ml}$, respectively. Baseline proportion of neutrophils and the levels of the MMPs and TIMP-1 were significantly higher in smokers compared to those of non-smokers in a cross sectional setting $(\mathrm{p}=0.021, \mathrm{p}$ $=0.014, \mathrm{p}=0.001, \mathrm{p}=0.02, \mathrm{p}=0.006$, respectively).

The IS neutrophil proportions increased significantly at 3 months after smoking cessation; $67.5 \pm 13.7 \%, 2.9 \pm$ $2.6 \times 10^{\wedge} 6$ cells $/ \mathrm{ml}(\mathrm{p}=0.035)$, but at 6 months the difference from non-smokers was no longer statistically significant $\left(38.2 \pm 14.4 \%, 0.74 \pm 0.83 \times 10^{\wedge} 6 \mathrm{cells} / \mathrm{ml}\right)$ (Figure 1). The individual levels of MMP-7, -8 and TIMP-1 at 3 months after cessation did not change significantly from the corresponding baseline levels of these same subjects. The corresponding individual levels after smoking cessation at 6 months decreased significantly compared to the baseline $(\mathrm{p}=0.032, \mathrm{p}=0.001, \mathrm{p}$ $=0.04$, respectively) (Figures 2, 3, 4 and 5). They also decreased nearly to the levels of non-smokers in the cross sectional evaluation, though there was high variability in the TIMP-1 levels. In contrast, the individual levels of MMP-9 increased significantly from the baseline at 3 months after cessation $(p=0.009)$ and did not differ significantly at 6 months after the cessation when compared to the baseline levels in these same 


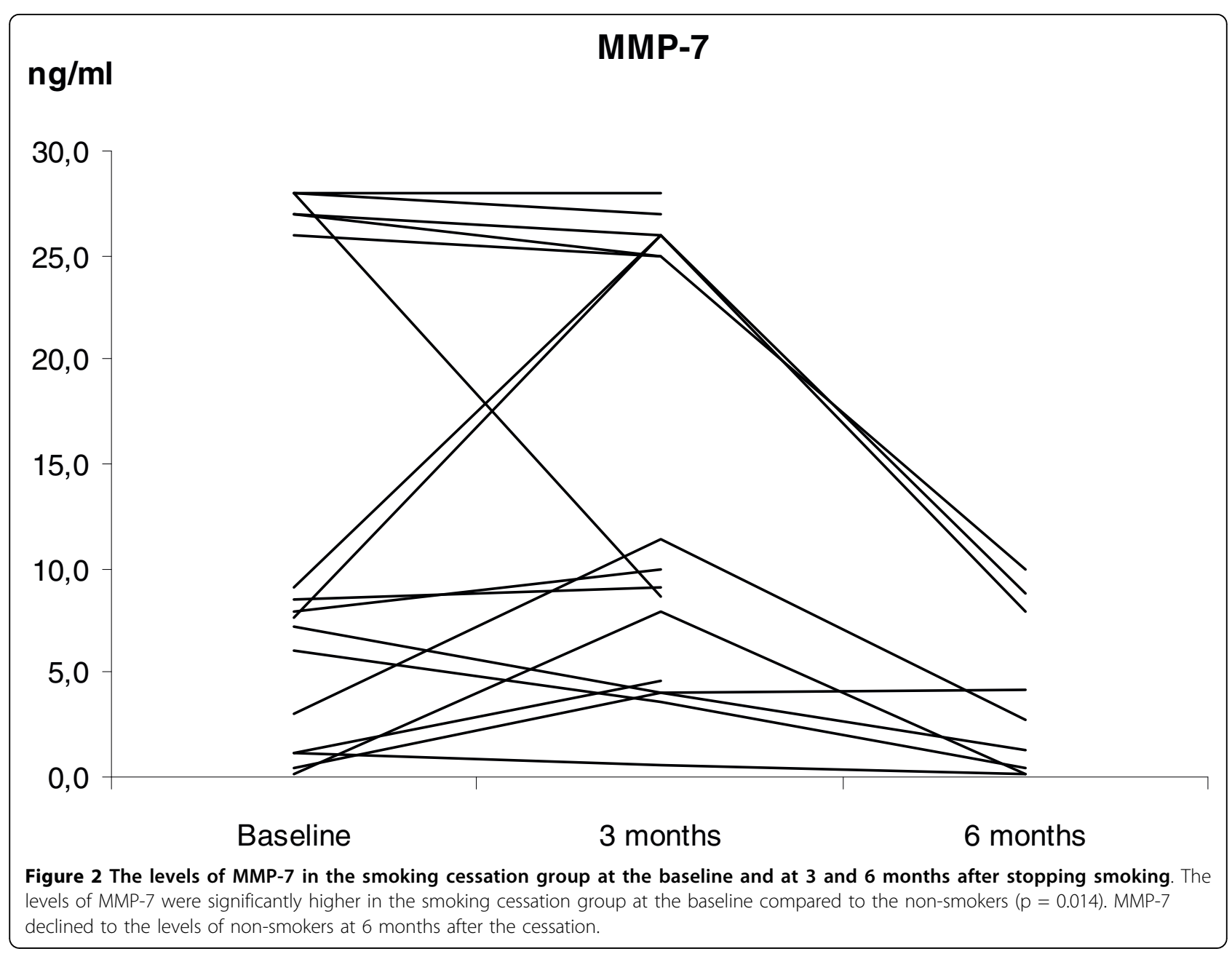

individuals $(\mathrm{p}=0.069)$, and the differences were even more significant when compared to the non-smokers in a cross sectional evaluation $(\mathrm{p}=0.017)$.

\section{Discussion}

As far as we are aware, this is the first prospective study to examine how smoking cessation is reflected in the levels of sputum MMPs. Most previous smoking cessation studies have been cross-sectional and the real effects of smoking cessation on airway remodelling processes/tissue destruction have remained unclear. Based on this study, it seems that sputum MMP levels generally decline slowly after smoking cessation. However, the elevated levels of MMP-9 in smokers are sustained for many months after giving up smoking for reasons that remain unclear.

Smoking cessation reduces COPD morbidity, hospital admissions [25] and COPD progression [1]. It has also been shown that symptoms decrease significantly after a month of quitting of smoking [8]. The decline of lung function is attenuated slowly, only after 2-3 years from smoking cessation [26,27]. Smoking evokes very similar airway pathology in asthma and COPD, with the typical features being the recruitment of increased numbers of neutrophils to the airways and elevated oxidative stress $[4,8]$. In this study, smoking resulted in neutrophil predominance and elevation of several MMPs in the IS of smokers with or without mild airway disease as compared to the situation in non-smokers. The fact that MMP-9 increased from the baseline during the 3-6 months after smoking cessation suggests that extracellular matrix breakdown continue in the airways for several months after an individual stops smoking. Since neutrophils are an important source of MMP-9, it could be argued that the elevated level of this MMP is simply a marker of neutrophilic inflammation. However, the finding of the persistently elevated MMP-9 levels after 6 months at a time when the neutrophil counts had returned to those encountered in non-smokers suggests that the rise in MMP-9 is not dependent on the numbers of neutrophils per se but instead reflects increased MMP-9 release. Our recent studies have shown that the elevated levels of 


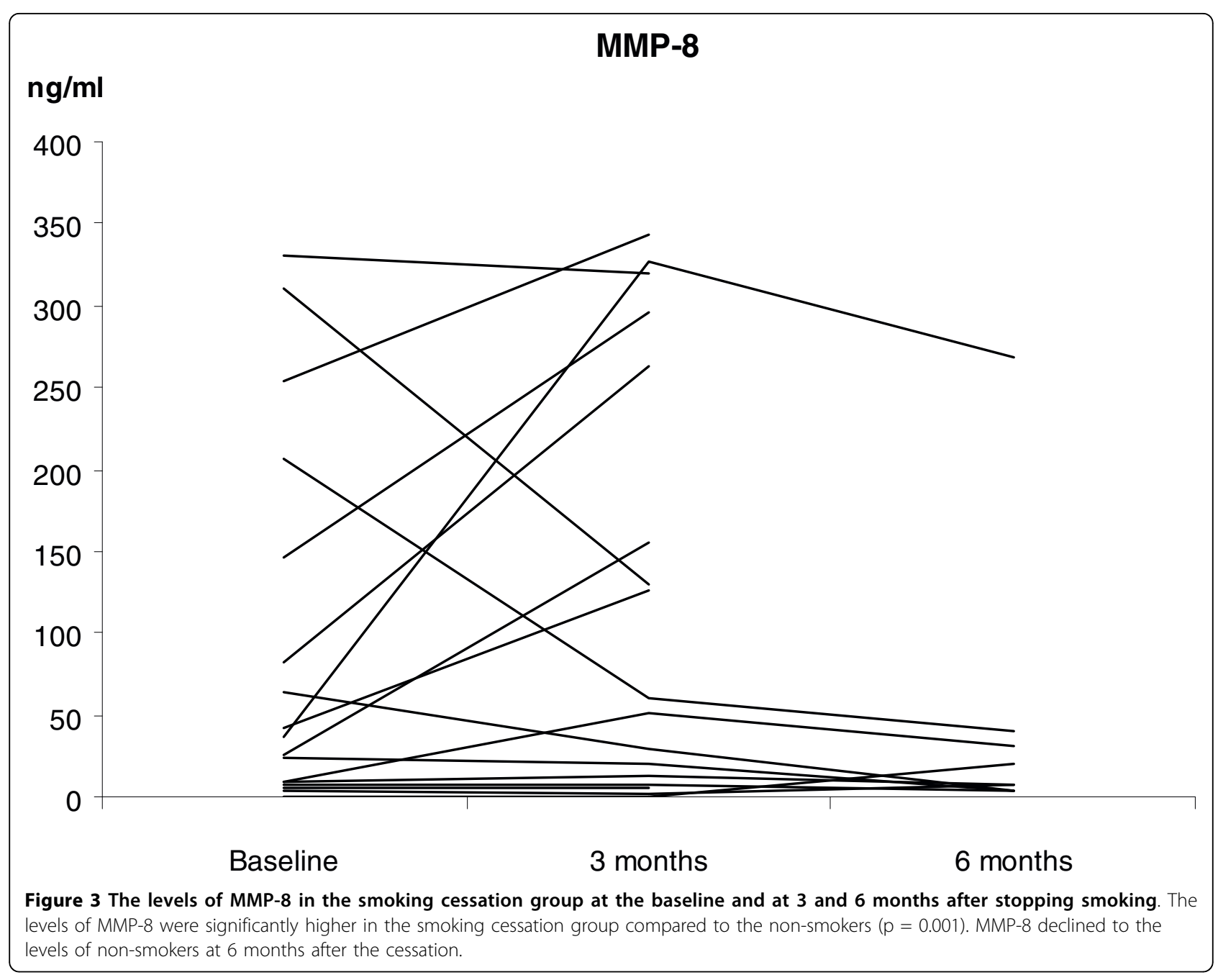

MMP-9 are associated with increased MMP-9 activity $[16,28]$. However, Lowrey et al. [29] have reported that MMP-9 protein but not MMP activity is higher in sputum of smokers with COPD when compared to smokers without COPD. The significance of MMP-9 in the airways needs further investigations, since it has also been suggested that MMP-9 may have protective role at least against ozone induced airway inflammation [30]. It needs to be emphasized also that our results are preliminary and final conclusions about the significance of sputum MMP-9 after smoking cessation remain unclear.

All of the other markers studied had returned to the levels of non-smokers by 6 months after cessation, which suggests that significant repair of tissue damage elicited by smoking has been initiated. A previous study noted that inflammatory markers such as macrophages and IL-8 declined significantly in asymptomatic smokers one year after smoking cessation [31]. This is in agreement with our results showing that MMP-7, -8 and TIMP-1 though its' variability can return to normal levels within 6 months after the patients successfully quits smoking. Baseline proportion of neutrophils and the levels of MMPs and TIMP-1 were significantly higher in smokers compared to those of non-smokers. These findings are in full agreement with the studies reporting that MMP-8, -9 and TIMP-1 are elevated in COPD and that the increased levels are related to smoking $[10,16,32]$ and also that the disease itself, not only smoking, results in MMP elevation [33-35]. MMP-7 is induced by hypoxia [36] but, as far as we are aware, this is the first study showing that MMP-7 elevation is provoked by smoking. MMP-7 is expressed by macrophages and expression is upregulated also in pulmonary epithelial cells in the presence of chronic infection, which might support the hypothesis that MMP-7 contributes to pulmonary immunity [37] and that smoking cessation decreases the chronic inflammation in the airways.

One weakness of this study was the high number of dropouts, despite our best efforts, only $15 \%$ of our subjects were still non-smoking six months later. This 


\section{MMP-9}

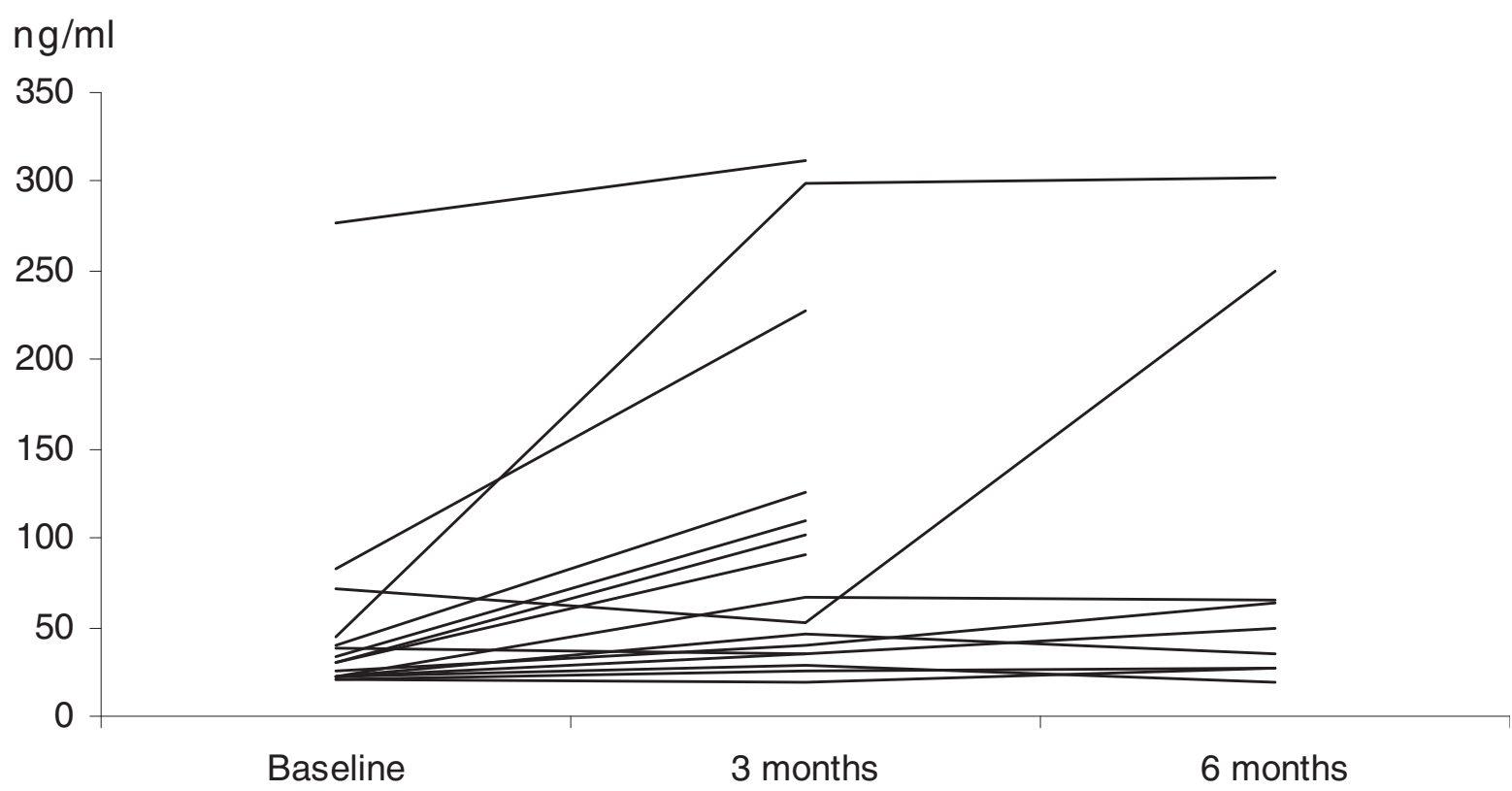

Figure 4 The levels of MMP-9 in the smoking cessation group at the baseline and at 3 and 6 months after stopping smoking. The levels of MMP-9 were significantly higher in the smoking cessation group compared to the non-smokers $(p=0.02)$. MMP-9 levels remained elevated in the smoking cessation group when compared to the levels of non-smokers at 6 months after the cessation $(p=0.017)$.

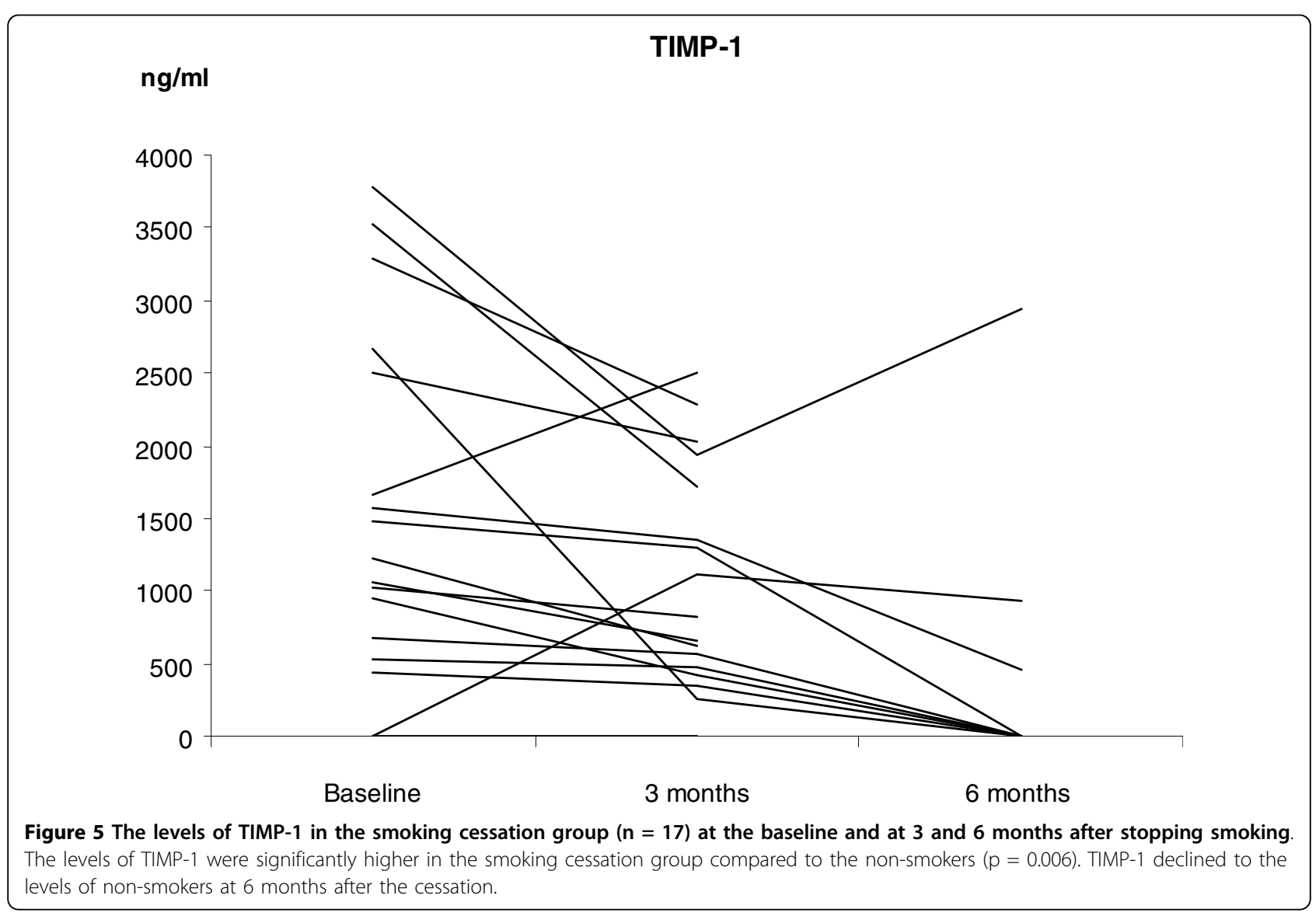


considerable numbers of the dropouts was to be anticipated taking into account the well-known difficulties associated with smoking cessation. In the study of Kaper et al. [38], for example, subjects receiving reimbursed smoking cessation treatment had an abstinence rate of $5.5 \%$ half a year after the interventions. In the present study, the cases from different subgroups were combined, which was also justified for several reasons i.e. the subjects were smokers who had no airway disease or the disease was mild. Smoking asthmatics also develop airway neutrophilia in a similar manner as smokers and subjects with COPD, and the same phenomenon was found in this study. Moreover, the differentiation of symptomatic smokers from mild COPD, and smoking asthmatics from COPD is a demanding task since there is a clear overlap in the cell profiles and diseases $[4,8]$. In our study, also the MMP levels were overlapping in these subgroups of smokers as expected. The high number of dropouts diminishes the power of this study, why these results, though important, require further investigations with larger numbers of patients with various phenotypes of asthma and COPD.

\section{Conclusions}

In summary, our study clearly suggests that the high levels of MMP-9 in the airways persist for at least 6 months after smoking cessation, and this does not appear to be related to the numbers of inflammatory cells in the airways. It is still unclear whether MMP-9 is one of the instigators to the ongoing disease progression in some individuals after smoking cessation or whether it has a protective role in airway inflammation.

\section{Acknowledgements \\ Tiina Marjomaa is acknowledged for the recruitment of patients and excellent technical assistance. This study was supported by Yrjö Jahnsson foundation, HUS EVO funds and Finnish Anti-tuberculosis Foundation Association.}

\section{Author details \\ 'Department of Medicine, Division of Pulmonary Medicine, University of Helsinki, Helsinki, Finland. ${ }^{2}$ Finnish Institute of Occupational Health, Helsinki, Finland. ${ }^{3}$ University of Helsinki, Helsinki, Finland. ${ }^{4}$ Department of Medicine, Division of Infection, Inflammation and Repair, Southampton General Hospital, Southampton, UK.}

\section{Authors' contributions \\ $\mathrm{NL}$ participated in the recruitment of non-smokers and smokers, and writing the manuscript. HS and WM helped with the statistics and writing. PR participated in the selection and recruitment of the smokers. VLK and RD participated in the design and coordination of the study, and writing of the manuscript. All authors have read and approved the final manuscript.}

\section{Competing interests}

The authors declare that they have no competing interests.

Received: 25 October 2009

Accepted: 14 March 2010 Published: 14 March 2010
References

1. Rabe KF, Hurd S, Anzueto A, Barnes PJ, Buist SA, Calverley P, Fukuchi Y, Jenkins C, Rodriguez-Roisin R, van Weel C, Zielinski J: Global strategy for the diagnosis, management, and prevention of chronic obstructive pulmonary disease: GOLD Executive Summary. Am J Respir Crit Care Med 2007, 176:532-555

2. Hogg JC, Chu F, Utokaprach S, Woods R, Elliot WM, Buzatu L, Cherniack RM Rogers RM, Sciurba FC, Coxson HO, Pare PD: The nature of small-airway obstruction in chronic obstructive pulmonary disease. N Engl J Med 2004, 350(26):2645-53

3. Anthonisen NR, Connett JE, Kiley JP, Altose MD, Bailey WC, Buist AS, Conway WA Jr, Enright PL, Kanner RE, O'Hara P, et al: Effects of smoking intervention and the use of an inhaled anticholinergic bronchodilator on the rate of decline of FEV1. The Lung Health Study. JAMA 1994, 272(19):1497-505.

4. Chalmers GW, Macleod KJ, Thomson L, Little SA, McSharry C, Thomson NC: Smoking and airway inflammation in patients with mild asthma. Chest 2001, 120:1917-1922.

5. Gibson $P G$, Simpson JL: The overlap syndrome of asthma and COPD: what are its features and how important is it?. Thorax 2009, 64(8):728-35.

6. Rutgers SR, Postma SD, ten Hacken NHT, Kauffman HF, Mark van der TW, Koëter GH, Timens W: Ongoing airway inflammation in patients with COPD who do not currently smoke. Thorax 2000, 55:12-18.

7. Laperre TS, Postma DS, Gosman MME, Snoeck-Stroband JB, ten Hacken NHT, Hiemstra PS, Timens W, Sterk PJ, Mauad T: Relation between duration of smoking cessation and bronchial inflammation in COPD. Thorax 2006, 61:115-121.

8. Louhelainen N, Rytilä P, Haahtela T, Kinnula VL, Djukanovic R: Persistence of oxidant and protease burden in the airways after smoking cessation. BMC Pulm Med 2009, 27(9):25.

9. Bergeron C, Tulic MK, Hamid Q: Tools used measure airway remodellation in research. Eur Respir J 2007, 29:596-604.

10. Elkington PT, Friedland JS: Matrix metalloproteinases in destructive pulmonary pathology. Thorax 2006, 61:259-266.

11. Barnes PJ: Mediators of chronic obstructive pulmonary disease. Pharmacol Rev 2004, 56:515-548.

12. Burke $B$ : The role of matrix metalloproteinase 7 in innate immunity. Immunobiology 2004, 209(1-2):51-56.

13. Lohi J, Wilson CL, Roby JD, Parks WC: Epilysin, a novel human matrix metalloproteinase (MMP-28) expressed in testis and keratinocytes and in response to injury. J Biol Chem 2001, 276:10134-10144.

14. Kinnula VL: Focus on antioxidant enzymes and antioxidant strategies in smoking related airway diseases. Thorax 2005, 60:693-700.

15. Culpitt SV, Rogers DF, Traves SL, Barnes PJ, Donnelly LE: Sputum matrix metalloproteases: comparison between chronic obstructive pulmonary disease and asthma. Respir Med 2005, 99:703-710.

16. Ilumets $H$, Rytilä $P$, Demedts I, Brusselle $G G$, Sovijärvi $A$, Myllärniemi M, Sorsa T, Kinnula VL: Matrix metalloproteinases $-8,-9$ and -12 in smokers and patients with Stage 0 COPD. Int J COPD 2007, 2(3):369-379.

17. Demedts IK, Brusselle GG, Bracke KR, Vermaelen KY, Pauwels RA: Matrix metalloproteinases in asthma and COPD. Curr Opin Pharmacol 2005, 5(3):257-63.

18. Djukanovic R, Sterk PJ, Fahy JV, Hargreave HH: Standardised methodology of sputum induction and processing. Eur Respir J 2002, 37(Suppl):1 s-2s.

19. Louhelainen N, Myllärniemi M, Rahman I, Kinnula VL: Airway biomarkers of the oxidant burden in asthma and chronic obstructive pulmonary disease: current and future perspectives. Int J Chron Obstruct Pulmon Dis 2008, 3(4):585-603.

20. [GINA] Global Initiative for Asthma: Global strategies for asthma management and prevention. NIH Publication, No 02-3659 National Institutes of Health, National Heart, Lung and Blood Institute. [online] 2002http://www.ginasthma.com.

21. Pauwels RA, Buist AS, Calverley PM, Jenkins CR, Hurd SS: Global strategy for the diagnosis, management, and prevention of chronic obstructive pulmonary disease. NHLBI/WHO Global Initiative for Chronic Obstructive Lung Disease (GOLD) Workshop summary. Am J Respir Crit Care Med 2001, 163:1256-1276.

22. World Medical Association: Declaration of Helsinki: Ethical Principles for Medical Research Involving Human Subjects. 2004http://www.wma.net/ en/30publications/10policies/b3/index.html.

23. ATS/ERS: Standardization of spirometry. Eur Respir J 2005, 26:319-338. 
24. Viljanen AA, Halttunen PK, Kreus KE, Viljanen BC: Spirometric studies in non-smoking healthy adults. Scand I Clin Lab Invest 1982, 159:5-20

25. Godtfredsen NS, Vestbo J, Osler M, Prescott E: Risk of hospital admission for COPD following smoking cessation and reduction: a Danish population study. Thorax 2002, 57:967-972.

26. Burchfiel CM, Marcus EB, Curb JD, Maclean CJ, Vollmer WM, Johnson LR, Fong KO, Rodriguez BL, Masaki KH, Buist AS: Effects of smoking and smoking cessation on longitudinal decline in pulmonary function. Am J Respir Crit Care Med 1995, 151:1778-1785.

27. Townsend MC, DuChene AG, Morgan J, Browner WS: Pulmonary function in relation to cigarette smoking and smoking cessation. Prev Med 1991, 20:621-637.

28. Ilumets $H$, Rytila PH, Sovijärvi AR, Tervahartiala T, Myllärniemi M, Sorsa TA, Kinnula VL: Transient elevation of neutrophil proteinases in induced sputum during COPD exacerbation. Scan J Clin Lab Invest 2008, 9:1-6.

29. Lowrey GE, Henderson N, Blakey JD, Corne JM, Johnson SR: MMP-9 protein level does not reflect overall MMP activity in the airways of patients with COPD. Respir Med 2008, 102(6):845-51.

30. Yoon HK, Cho HY, Kleeberger SR: Protective role of matrix metalloproteinase-9 in ozone induced airway inflammation. Environ Health Perspect 2007, 115:1557-1563.

31. Willemse BWM, ten Hacken NHT, Rutgers B, Lesman-Leegte IGAT, Postma DS, Timens W: Effect of 1-year smoking cessation on airway inflammation in COPD and asymptomatic smokers. Eur Respir J 2004, 26:835-845.

32. Vernooy JH, Lindeman JH, Jacobs JA, Hanemaaier R, Wouters EF: Increased activity of matrix metalloproteinase-8 and matrix metalloproteinase-9 in induced sputum from patients with COPD. Chest 2004, 126:1082-1010.

33. Demedts IK, Morel-Montero A, Lebecque S, Pacheco Y, Cataldo D, Joos GF, Pauwels RA, Brusselle CG: Elevated MMP-12 protein levels in induced sputum from patients with COPD. Thorax 2006, 61(3):196-201.

34. Babusyte A, Stravinskaite K, Jeroch J, Lötvall J, Sakalauskas R, Sitkauskiene B: Patterns of airway inflammation and MMP-12 expression in smokers and ex-smokers with COPD. Respir Res 2007, 14(8):81.

35. Deshmukh HS, Shacer C, Case LM, Dietsch M, Wesselkamper SC, Hardie WD, Korfhagen TR, Corradi M, Nadel JA, Borchers MT, Leikauf GD: Acroleinactivated matrix metalloproteinase 9 contributes to persistent mucin production. Am J Respir Cell Mol Biol 2008, 38(4):446-54.

36. Burke B, Giannoudis A, Corke KP, Gill D, Wells M, Ziegler-Heitbrock L, Lewis CE: Hypoxia-induced gene expression in human macrophages: implications for ischemic tissues and hypoxia-regulated gene therapy. Am J Pathol 2003, 163:1233-1243.

37. Dunsmore SE, Saarialho-Kere UK, Roby JD, Wilson CL, Matrisian LM, Welgus HG, Parks WC: Matrilysin expression and function in airway epithelium. J Clin Invest 1998, 102(7):1321-31.

38. Kaper J, Wagena EJ, Willemsen MC, van Schayck CP: Reimbursement for smoking cessation treatment may double the abstinence rate: results of a randomized trial. Addiction 2005, 100(7):1012-1020.

\section{Pre-publication history}

The pre-publication history for this paper can be accessed here:http://www biomedcentral.com/1471-2466/10/13/prepub

\section{doi:10.1186/1471-2466-10-13}

Cite this article as: Louhelainen et al.: Elevation of sputum matrix metalloproteinase-9 persists up to 6 months after smoking cessation: a research study. BMC Pulmonary Medicine 2010 10:13.

\section{Submit your next manuscript to BioMed Central and take full advantage of:}

- Convenient online submission

- Thorough peer review

- No space constraints or color figure charges

- Immediate publication on acceptance

- Inclusion in PubMed, CAS, Scopus and Google Scholar

- Research which is freely available for redistribution

Submit your manuscript at www.biomedcentral.com/submit 